\title{
Engaged pedagogy and responsibility: A postcolonial analysis of international students
}

\begin{abstract}
:
This paper responds to increasing discussions about responsibility within geography by exploring some of the spatialities imbued in thinking responsibly about internationalisation in the UK Higher Education system, and it uses the over-determined categorisation of the international student as a way in to this exploration. Although international students have been considered from the viewpoint of migration studies, global education studies and critical pedagogical studies, this paper attempts a postcolonial analysis of international students, to consider what forms of pedagogic responsibility are called forth through this framework. Building on bell hooks' call for an 'engaged pedagogy', this paper shows that routing care and responsibility through postcolonial geographies incites a more sharply demanding political praxis.
\end{abstract}

Keywords: engaged pedagogy, postcolonialism, responsibility, care, international students 


\section{Engaged pedagogy and responsibility: A postcolonial analysis of international students}

\section{Introduction}

The spatiality of responsibility has been a theme that has received considerable attention from geographers. Thus, geographers have spelt out some of the theoretical bases for responding to

'the claims of distant strangers' (Barnett and Land, 2007; Brock, 2005; Corbridge, 1993) and arguing that responsibility for global poverty is spread far beyond the people who feel its weight (see Echanove, 2005). Doreen Massey (2004) makes this responsibility clear when she suggests that global cities like London need to take responsibility for the exploitation that now brings, and historically has brought them, the resources to establish and maintain their status. She therefore highlights the need to recognise 'how those small and highly differentiated bits of all of us which position us as 'Londoners' give rise to responsibility towards the wider relations on which we depend' (Massey, 2004, 17).

This relationality and responsibility extends to academic practices too, requiring us as academics to take active steps to recognise the complex spatial relationships between British academic geography and its postcolonial publics (Bonnett, 2003). In this paper we wish to explore some aspects of this spatiality through the example of international students studying in the UK's Higher Education Institutions (UKHEI) ${ }^{\mathrm{i}}$.

This focus is important for international student mobility has risen by over 300 percent in the last 25 years (Brunch and Barty, 1998, 18), with active recruitment taking place by many universities in the UK, Australia and the US. There has been a corresponding rise in the contribution that 
international students now make to the total student population in many countries ${ }^{\mathrm{ii}}$. In the UK, for example, the Higher Education Statistics Agency (HESA) shows that in 2005/06 there were 330,060 international students, representing $13 \%$ of the total English student population, $15 \%$ in Scotland, $12 \%$ in Wales and $11 \%$ in Northern Ireland (http://www.ukcosa.org.uk/pages/hestats.htm accessed July 2007iii). But the significance of international students is not simply about numbers or their proportions within the whole student body. Rather, it is the relative neglect of the questions they pose for thinking responsibly about academic geography, that is of particular interest here. International students thus offer an 'obvious place' (Barnett, 1995) from which to engage with how responsibility may be enacted, or disavowed, through everyday academic lives ${ }^{\mathrm{iv}}$.

To do this, the paper unravels how responsibility and care of international students can be informed by the spatial challenges of a postcolonial frame. In drawing on a postcolonial analysis (see Raghuram et al, this issue), the paper challenges contemporary debates that seek to present the internationalisation of $\mathrm{UKHE}^{\mathrm{v}}$ as a 'neutral experience' within normalizing conceptions of internationalisation, and instead moves towards a more 'layered' understanding that highlights the connections between the geographical, historical, political, economic and cultural spheres in order for an 'engaged pedagogy' to emerge. This approach is important, for according to Rizvi et al. (2005), contemporary debates about the relationship between globalisation and education tend to reify the latter and provide universalising explanations that fail to adequately address specific historical and political contexts. They therefore suggest that postcolonial theories can perform a valuable role in showing how 'contemporary social, political, economic and cultural practices continue to be located within the processes of cultural domination through the imposition of 
imperial structures of power' (Rizvi et al., 2005, 1). Thus this paper traces some ways in which academics' responsibilities towards (all) students are shaped by the complex spatialities that are inherited, at least in some part, both from the history of colonialism and the implications of these historical connections for present-day transnational relationships. In doing so, we take up Gilmartin and Berg's $(2007,123)$ criticism that 'British postcolonial geography is dominated by critiques of the discursive construction of historical colonialism', and rather we actively focus on 'the aftermath and continuation of colonialism' in academic practices. This intervention in 'the contemporary' is particularly important at a time when postcolonialism has been criticised for failing to understand current conditions (Lavia, 2007, 288).

Our use of the terms care and responsibility are routed through a postcolonial frame. Both terms have a multiplicity of meanings in the literature. In considering care, for example, distinctions have been made between taking caring of, caring about, care-receiving and care-giving (Tronto, 1993), between care as motivation and care as an end (Sander-Staudt, 2006) and between care as ethic and care as practice (Popke, 2006). Meanwhile responsibility has been considered with respect to responsibilities towards the so-called 'distant stranger' (Corbridge, 1993), responsible research praxis and citizenship (Gibson, 2006), responsible consumption (Barnett et al., 2007) and responsibilities towards the environment (Hobson, 2006). In this paper we specifically build on the literature that explores the relationships between postcolonialism (as a marked category), responsibility and care (see for example, Bosco, 2007). As such, we consider care and responsibility in the context of past and present inequalities in a postcolonial world, an approach which insists upon a 'care-full' recognition of postcolonial interaction and the spatialities involved therein. This approach contests the bases upon which responsibility and care have 
largely been constructed thus far, by challenging the idea of proximate and distant relations (Barnett et al., 2008) and by questioning the centre from which care and responsibility can be talked about. (For a more comprehensive discussion of a postcolonial analysis of care and responsibility see Raghuram et al, this issue). So a postcolonial approach to responsibility and care is adopted in this paper, in both rethinking the spatialities involved in international student mobility and in sensitising ourselves to the 'voice' through which such concerns are usually articulated.

The rest of the paper is divided into four sections. In the first section, we briefly review current debates on international students which reveal the lack of literature specifically focusing on the complex relational ties involved in caring for and thinking responsibly about international students. In the second section we therefore suggest that a postcolonial analysis is of great help in bringing out these relationalities and responsibilities, in particular in working towards an 'engaged pedagogy' that is informed by a more complex view of what it means to be 'international'. In the third section, we outline some ways in which a postcolonial frame enables a re-thinking of these spatialities of responsibility in the particular context of the internationalisation of UKHE. This moves us to conclude, in section four, that to articulate responsibility and care as a basis for a politics, we must explore the multiple historical materialities of spatial relationships. We argue that consciousness of geographically-routed power dynamics is necessary for generating forms of engaged political praxis. In other words, to consider responsibility and care as relational terms, is to take seriously how these terms might appear for those who are cared for and for whom we might be responsible. Ultimately, 
we want to ensure that there are no ossifying certainties about care and responsibility (cf Raghuram et al, this issue).

\section{International students: current debates}

The number of international students enrolling on courses at UK institutions more than doubled over the ten years from 1996-97 to 2005-06 (Tysome, 2007). In 2005/06, international students made up 11 percent of full-time first degree students, 65 percent of full-time taught postgraduates and 41 percent of all research postgraduates in the UKHE sector ${ }^{\mathrm{vi}}$. The top five non-EU sending countries were China (PRC), India, United States of America, Malaysia and Nigeria while the top five in the EU were Greece, Republic of Ireland, Germany, France and Cyprus (http://www.ukcosa.org.uk/pages/hestats.htm accessed July 2007, see also Table 1). Although international students are located throughout the UKHE sector, they are particularly concentrated in specific institutions, especially in London. For example, 64 percent of students at the London School of Economics and Political Science are classified as international, 37 percent at Imperial College of Science, Technology and Medicine and 32 percent at University College London. By contrast, the highest proportions of international students found outside London are located at The University of Oxford (26\%), Warwick University (25\%) and University of Cambridge (21\%). Similarly, international students are concentrated in special subject areas, with most students being located in Business and Administrative studies, Engineering and Technology and Social, Economic and Political Studies (http://www.ukcosa.org.uk/pages/hestats.htm accessed July 2007, see also Table 2). It is clear then that there are distinct spatial, temporal and sectoral patterns in international student demographics in UKHE Institutions ${ }^{\mathrm{vii}}$. 
Numerically, international students represent an important and growing component of $\mathrm{UKH}^{\mathrm{viii}}$. This growth in numbers of international students has been matched by growing academic debates about the issues that international student mobility presents ${ }^{\mathrm{ix}}$. In brief, this literature may be summarised as having three broad interests, as discussed below.

The first set of literatures may be said to be loosely focusing on migration and mobility of students within the context of migration policy (Waters, 2006). In this literature, students are also viewed as incipient skilled migrants (Kuptsch, 2005) in 'the race for skills' (Ziguras and Law, 2006) and migration is seen as one way of channelling skills that are in formation. By offering extension of stay for immigrants with the right skills (Tremblay, 2005) and preferential treatment in points-based systems of migration (Baas, 2006; Hazen and Alberts, 2006), international students are encouraged to contribute their newly acquired skills to developing the economies of destination states (Findlay and Stam, 2006; King and Ruiz-Gelices, 2003) or indeed to return home to economically 'develop' sending countries.

A second set of concerns centre around the pedagogic issues raised by student mobility. Much of this literature separately interrogates either educator practises, or students themselves in order to explore how to improve student experiences. For example, some studies have tried to explore why different educators respond differently to international students (Schuherholz-Lehr, 2007) in order to outline the kinds of shifts in educator behaviour that might be necessary. Others have focused on educators, not just as purveyors of curriculum but as producers of what counts as knowledge, suggesting that the curriculum might need to be explored in the context of rising 
numbers of international students (Haigh, 2002; Jackson, 2003). Singh and Doherty (2004) and Asmar (2005), for example, are mindful of the dilemmas of balancing issues of cultural sensitivity against assimilation within prevailing curricula whilst Bradley (2000) has questioned the ability, in practice, for university educators to transcend different socio-cultural value systems. Research on student experiences, on the other hand, unpicks impediments to the international students' learning experience (Scheyvens et al., 2003). This literature highlights the pedagogic dilemmas posed by students' knowledge and use of English in both written work and oral classroom culture in ways that are familiar or are validated by their teachers and assessors. Differences in the nature of academic hierarchies (and hence what can be said by students to their teachers), rhetorical tradition and educational styles (typically with an overemphasis on memory) too are cited as significant in disadvantaging international students (Koehne, 2006). However, more critically aware work has challenged the cultural stereotyping of international students as simply erasing the different forms that the hierarchies, stereotypes and linguistic styles take in receiving contexts (Bullen and Kenway, 2003). Thus, Tucker (1995), for instance, argues that students are not only products of culture but also produce their own pedagogic cultures, which will appeal to diverse readers. Hence, a second strand of literature is developing which aims to move from how to make international students recognise, adapt and conform, to how teachers and international students might together craft pedagogical styles that serve the political purposes of academic practices. This is a literature which moves to more clearly tie educator and student together in dialogic processes.

Most productive for us is a third strand of work that explores international students as an inherent part of wider processes of internationalisation of HE. For instance, there is an evolving literature 
which includes the development of offshore campuses and exchange programmes. This range of work considers the political, cultural and economic effects and policies of internationalisation/globalisation of HE (Gacel-Ávila, 2005; Kong, 2007a; Schoorinan, 1999). It also explores the governability of the global 'eduscape' (Luke, 2005). Teichler (2004), for example, debates whether globalisation of HE can be viewed as a manifestation of 'turbocapitalism' or whether it should be viewed instead as a move towards 'global understanding' while Burbules and Torres (2000) have critiqued this universalized approach to understanding education and globalization, arguing for the need to foreground the significance of contextual socioeconomic factors in understanding changing education patterns.

\section{Framing a postcolonial 'engaged pedagogy'}

It is this third vein of literature about the process of internationalisation of HE that we want to add to, but we want to do this from a postcolonial frame. This is because the ambivalence of the longstanding engagement between postcolonial theory and education can set the conditions for rethinking an internationalised HE sector. Thus, according to Rizvi et al. (2006, 257): 'Postcolonialism's contentions, surrounding the relationship between knowledge and power, are linked directly to education, both as an institution where people are inculcated into hegemonic systems of reasoning and as a site where it is possible to resist dominant discursive practices. In this way, education has a systematically ambivalent relation to postcolonialism. On the one hand, it is an object of postcolonial critique regarding its complicity with Eurocentric discourses and practices. On the other hand, it is only through education that it is possible to reveal and resist colonialism's continuing hold on the geographical imagination. Education is also a site where legacies of colonialism and the contemporary processes of globalization intersect.' Thus our aim 
in pursuing a postcolonial analysis is to deploy the figure of the international student as a globalised agent, capable of forging a truly global discipline (and before which the carefully bounded agency of the 'active learner' rather pales, see Biggs, 2003 and Haggis, 2003). In so doing, we do not focus on how to teach the international student, as if this category of student somehow exclusively embodied difference in terms to teaching: to do that would be to overdetermine the term 'international' as a marker of difference, homogenising both the 'home' student (despite longstanding recognition of the salience of for example age, gender, class, and ethnicity in pedagogy and performance) and international' students (who are also internally differentiated in terms of nationality in addition to other markers of identity). Our aim in using a postcolonial analysis is to focus on that very porousness of the lecture room wall that is highlighted by the complex geographies of international students, to insist that, in order to be responsible to all students, 'pedagogy is removed from limited notions of instrumentalist values of instruction and didactic relationships with students. Rather, pedagogy is considered as having political and strategic intent, linking histories and biographies with issues of culture, power and politics' (Lavia, 2007, 297).

Reference to bell hooks' concept of 'engaged pedagogy'is particularly instructive here. In Teaching to Transgress (1994, 13) hooks argues emotively for a progressive, holistic, participatory education, an 'engaged pedagogy', one that 'cares for the souls' of students. To be able to care, hooks argues, will place demands upon educators in terms of authenticity and commitment. So for hooks, engaged pedagogy is more demanding than critical or feminist pedagogy because it insists that the teacher has the responsibility to work towards selfactualization, to be aware of themselves as practitioners and as human beings, if they wish to teach students in a non-threatening, anti-discriminatory, empowering way. So for hooks, self- 
actualisation should be the goal of the teacher as well as the student although she recognizes that this is not easy: 'It was difficult to maintain fidelity to the idea of the intellectual as someone who sought to be whole- well-grounded in a context where there was little emphasis on spiritual well-being, on the care of the soul. Indeed, the objectification of the teacher within bourgeoisie educational structures seemed to denigrate notions of wholeness and uphold the idea of the mind/body split, one that promotes and supports compartmentalization.' In order to resist this split, hooks adopts Thich Nhat Hanh's philosophy of engaged Buddhism, with the focus on practice in conjunction with contemplation, and notes its similarity to Freire's focus on 'praxis'action and reflection upon the world in order to change it.

For hooks then $(1994,33)$ : 'To commit ourselves to the work of transforming the academy so that it will be a place where cultural diversity informs every aspect of our learning, we must embrace struggle and sacrifice.' In embracing this struggle, hooks' (2003) pedagogy is one that is responsive to the specific situation of each particular group of students and she sees education as taking place not only in the classroom but also outside formal teaching contexts. This chimes with our emphasis on the porousness of lecture room walls, but unlike hooks we want to focus on how what is happening outside the classroom actually shapes classroom pedagogies. This project is, then, not simply about teaching practices in relation to international students, but rather one of thinking about the discourses, power hierarchies, and social relations that shape international students' presence in the UK. Such an approach is really important, for not only has previous work on international students tended to be seriously undertheorised in Britain (Walker, 1999) but according to Leonard et al $(2003,20)$, this research to date tends to be '...pragmatic, implicitly positivistic.... and rarely presented in the context of current higher education policy and governance...This means that the experiences of international students are often examined 
without consideration of the environment that frames them.' Hence, concern here is not limited to caring for students i.e. the face-to face care that is involved in the classroom but also extends to caring about the international conditions that shape students' experiences (Tronto, 1993). It is the productive possibilities of thinking about internationalisation and its particular spatialities as part of engaged postcolonial pedagogy where our particular contribution lies.

\section{Re-thinking the multiple spatialities of international students}

In this section we therefore begin by laying out the discursive frames through which internationalisation is generally framed by UK policy makers. We then move on to highlight the 'limits, silences and problems' inherent in these current ways of thinking about international students in order to open up internationalisation to a more power-laden, critical and emotional analysis. We do this by making apparent the (often hidden) multiple spatialities of international students.

\section{Discursive framings}

The growth in international student numbers in the UK has been supported by three main discursive frames. The first frame supporting the drive for recruiting international students to UKHE is a recognition of the importance of international students to the financial health of UK universities (and beyond). International student recruitment has helped to keep UKHEIs, and especially particular courses within some institutions, viable within the context of falling numbers within the university going age-group. Tysome (2007), for example, reported that in 2005-06, more than a fifth of students enrolled on courses in strategic subjects such as 
engineering, mathematics, computer science, physics and chemistry, came from outside the UK - and at postgraduate level, international students represented nearly half of those joining courses in these areas. International students were particularly prevalent in electronic and electrical engineering, chemical and energy engineering, metallurgy, minerals technology, and agricultural sciences - making up about a third of full-time students in these disciplines, which were all finding it hard to attract UK students in 2005-06. Moreover, the high fees charged to international students have also enabled the government to increase the number of UK students in HE without a proportionate increase in taxes (Findlay and Stam, 2006, 4).

Thus recent estimates suggest that international student fees contribute more than 1.5 billion to British universities (Asthana, 2007, 17) and that almost ten percent of all HE teaching income comes from non-EU student fees (Ramsden, 2001). In addition, a British Council report put the export value of education and training as a whole at $£ 28$ billion, more than the financial services and car industries (Attwood and Tahir, 2007) while a HE Report from Universities UK reported that from 2001-02 to 2005-06, a 52 per cent increase in tuition fee income was 'to a considerable extent' attributable income from to international students (Tysome, 2007). The Higher Education Policy Institute (HEPI) also estimated that fee income and living expenditure from overseas students from outside Europe contributed at least $£ 3.3$ billion annually to the UK economy whilst the rise in gross domestic product resulting from international students who stay to work in the UK was estimated to be about $£ 1$ billion a year (Newman, 2007a). International students have thus helped to allay the running costs of UK HEI but have also contributed to the growth of local economies through their spending (see Table 3). And this has been achieved through what 
Khadria (2001) calls the 'silent backwash of remittances', money flowing out from poorer countries to richer countries in the form of overseas student fees (see especially Khadria, 2007) ${ }^{\mathrm{x}}$.

Insert Table 3 here

But the contribution of international students is not limited to the financial fate of universities but also extends to a recognition of their role in research within the context of wider decline in research and development funding in the UK. The magnetic ability of the US to recruit researchers from across the world, including the UK, it is feared will lead to a decline of UK universities' competitiveness vis-à-vis US universities. The attempt to address the 'skills gap' in science and engineering, through student and worker immigration (Findlay and Stam, 2006) is thus, the second discourse framing increased international student recruitment. It is hoped that this migration of highly-skilled persons will help the UK to maintain a competitive edge within the context of 'knowledge societies'.

However, it is also recognised that international students will help to constitute the body of UK HEI but will also increase the international reach of the UK. This third discourse thus relates to the UK's attempt to improve its 'global presence' more generally. So international education has been branded as a 'wider good', whereby the UK takes up its responsibilities in a globalising world. Thus the UK Council for International Education (UKCOSA) suggest that:

'international diversity on our campuses enriches the environment for all staff and students. Perhaps most importantly, their familiarity with the UK will allow them to influence others - positively or negatively, depending on their experiences - both in their home countries and wherever else in the world they go. Over and above our responsibility to ensure a higher quality of experience for all of our students, as future partners in diplomacy, trade and cultural exchange, and as people likely to 
become influencers and decision-makers, we should take very seriously the question of whether international students' experiences of the UK are positive' (UKCOSA, 2004, 2) ${ }^{\mathrm{xi}}$.

This targeting of international students as 'cultural ambassadors' for UK HEIs is part of wider moves to both internationalise $\mathrm{HE}$ and to recognise international students' role in the wider 'securitisation' of both knowledge and of migration.. Initiatives developed to internationalise UKHE include the UK-India Education and Research Initiative (UKIERI), which was set up in 2005 to substantially improve educational links between the UK and India (see http://www.ukieri.org/). Similarly, the Development Partnerships in Higher Education (DeLPHE) initiative in 2006 aims to support partnerships between HEIs in the UK and overseas to 'find new ways to fight global poverty'. Specifically DeLPHE will encourage projects aiming to promote science and technology in Africa and Asia (see http://www.britishcouncil.org/learning-delphe.htm). International education thus becomes framed as part of 'good global citizenry' whist also ensuring that international students become bearers of sensitive knowledge of places that are economically, as well as geopolitically, important to the UK.

Thus, the discourses surrounding the current growth in international student numbers in the UK are quite complex. Overall, government policies have been based on recognising, although not necessarily respecting, the constitutive role of international students in buttressing the UK economy, its HE institutions and also in helping the UK to make a 'place in the world'. But these discursive frameworks only highlight 'one side of the equation'- what international students can 'do' for the UK. What remains hidden beneath these discourses is the mutuality, the interdependence and mutual constitution of UKHEIs and international students. What we wish to 
do now is to unsettle these normalising, partial frameworks, by thinking through the internationalisation of UKHE from a postcolonial perspective, which involves a recognition of both the connections, disconnections and new connections of co-constitution that shape the international student experience. These involve both colonial spatial imaginaries and how these weave into postcolonial connections to influence the internationalisation process today. In the next section we therefore move towards re-conceptualising the relationships both inside and outside the classroom, to see international students as part of wider internationalisation processes both in the past and in the present, and thus to interrogate the category 'international' in the oft used category international students. In doing so, we will focus on the complex relational ties involved in the internationalisation of $\mathrm{HE}$, and consequently the implications of this for academic practice in caring for and thinking responsibly about, not only international students, but all students in an internationalised system.

\section{Colonial spatial imaginaries}

The international spaces most easily reached, and most apparently 'obvious' are those to which the UK has been linked through colonial heritage. Thus the initial impetus for many international students to come to study in Britain was rooted in the structures of academic imperialism that emanated from the colonial period, in which a qualification gained from the 'mother country' attained considerable cultural, economic and emotional value. This long-standing influence of Western education in creating the colonised mind (Bhabha, 1993) has been of considerable interest to postcolonial writers for a long time. And its effects can also be felt through this excerpt from Jamaica Kincaid's (1996, 59-60) fictional autobiography set in Trinidad, where the main protagonist in the novel talks of her educational experience: 
'I also knew the history of an array of people I would never meet. That in itself should not have kept me from knowing of them; it was only that this history of peoples that I would never meet-Romans, Gauls, Saxons, Britons, the British people-had behind it a malicious intent: to make me feel humiliated, humbled, small.... Once I had identified and accepted this malice directed at me, I became fascinated with this expression of vanity: the perfume of your own name and your own deeds is intoxicating, and it never causes you to feel weary or exhausted; it is its own inspiration, it is its own renewal.'

Kincaid here reveals how education as a colonial project was focused on encouraging the colonised mind (see Wa Thiong'o, 1981) but crucially was also always mirrored by an affirmation of the colonising subject - as Achille Mbembe argues: 'The subject that the colonizer is, is a subject stiffened by the successive images he or she makes of the native... That is why, to exist, the colonizer constantly needs the native as that animal that serves as the support for the colonizer's self-consciousness' (Mbembe, 2001, 188).

However, knowledge has never been simply or completely 'transferred' from 'centre' to 'margin'. Colonial knowledge aggregated, mushroomed, was disturbed and found an altered voice in particular institutional settings. Thus Mills (2006) offers a forceful account of British late-colonial efforts to export its model of HE to Africa. In his paper he challenges any simple interpretation of the 'Asquith commission' university colleges - such as Makerere or University College Ibadan - as alien impositions or colonial intellectual 'hothouses'. Focusing on Makerere University in Uganda, and drawing on a variety of archival and personal sources, he shows how its students and faculty engaged in an ambivalent recreation and subversion of the Western idea of the university and its foundational discourses. He thus suggests that the institution offered a space to question and debate the purpose of an African university education. Students and staff made use of their limited political autonomy to challenge and rework the colonial hierarchies of 
race and culture. As a result, Makerere remained an influential forum for intellectual debate, cultural expression and social critique until the mid 1970s and, according to Hill (2006), remains an important historical legacy from which to rethink the future of African universities.

Further, a focus not only on the complications of education and colonialism but also on education and anti-colonialism highlights the strategic importance of international students as a sharply influential group in the first half of the twentieth century in shaping anti-colonial movements. Lahiri (2000), for example, gives a compelling account of how Indian students studying in Britain prior to the two world wars would later shape both the nationalist movement in Indian and construct policies in the newly independent Indian nation after 1947. What is interesting here is that colonial education did not appear only as legacy but rather came to spark new spatial imaginaries - including those of an independent nation. As many postcolonial writers have acknowledged, internationalism was an inherent part of nationalism (James, 1998).

In an interview with David Scott, George Lamming, a famous Barbadian novelist, fleshes out some of the complexities of colonial inheritances of spatial imaginaries (Scott, 2002). First, he talks about the huge influence that visits to the house (and even more so the library) of a French and English teacher, Frank Collymore, in Trinidad had on him. In particular, it led him to the discovery that there were a people and a history outside something called the British Empire and Barbados. So despite the proximity of other Caribbean islands, it was the incommensurable distance between the islands (particularly between Barbados and the islands that were not part of the British Empire) that became apparent to Lamming. Thus rrelationships with one place can be produced at the expense of that with others. Spaces which are not linked through the history of 
empire, though physically proximate, may be distanciated and this distanciation is often a technique of ruling. Awareness of some relations gets occluded, other heightened. Secondly, the interview provides a glimpse into the tremendous intellectual fervour of these meetings not only in Collymore's house in Trinidad but also later in the UK to which he moved as a writer, and where Lamming met many of those who had a formative influence on him. Significantly, was a sense of a Caribbean identity that emerged from these meetings in the UK. This development of pan-Caribbeanness within the UK is also noted by Winston James $(1993,255)$ :

'Caribbeans in Britain and North America have a better sense of and empathy for the cultures of the Caribbean as a whole than the majority of their counterparts who reside in the Caribbean itself.'

So here we get a glimpse of the ways in which a postcolonial analysis of education in relation to the 'international student' is not only about the mutual constitution of ex-colony and excoloniser, but is also about the constitution of a range of relationships between spaces that are not entirely determined through their relations with each other, indeed may even strongly resist being so (Mufti, 2005). As we have seen, colonialism, anti-colonialism and distance (sometimes as (in)difference) have all left their legacy on knowledge in different geographical contexts. It highlights the wide range of spatial imaginaries, based not only on exclusivity and separateness (as in the case of independence movements) and not only on historical connection, but also on new spaces of affiliation and belonging that already exist and can be drawn upon on thinking in an engaged manner about international students. Being a part of, but still being apart from, therefore entails responsibilities to both take account of and be accountable to, both the connections and the disconnections, these different spaces and their distinctive world picturing (cf Noxolo et al., 2008). It particularly requires academic geographers to recognise the fluidity of the incredibly rich spatial imaginaries that internationalisation may bring with it. 


\section{Postcolonial legacies}

These interconnected imaginaries have, at least to some extent, continued through the postcolonial era, enabled- indeed facilitated precisely - through the mobile bodies of international students. For instance, Ock Park (2004) shows how Korean modern geography has grown rapidly since the 1960 s, being greatly influenced by the Korean geographers who received $\mathrm{PhD}$ degrees in the United States and returned home to teach at universities in Korea, especially in the 1970s and early 1980s. According to Ock Park (2004), American geography has directly and indirectly influenced the progress of geography in Korea in various ways — education systems, curricula for college students, training graduate student and research methodologies. In this way, postcolonial writers have always been clear that wider international power relations and inequalities structure both the teaching practices and the knowledge content of pedagogical practice, so that the walls of the lecture room are inevitably porous.

Thus recognition of what internationalisation might mean begins with a fuller awareness of the agency of international students in the construction of geographical knowledge, variously constructed in different geographical contexts. For instance, Kong (2007a, 14) suggests that 'the historical pathways of a country's development as well as its institutions and policies shape the kind of geographical knowledge (re) produced in each national context'. So in China in the contemporary period, for example, the state wields a strong influence on HE, including recommending the text books that should be used (Xiaojian et al, 2007). In South Africa, by contrast, Mather (2007) documents how the development of the geography discipline reflects the apartheid legacies of the country whilst more recent research agendas have focused on applied 
questions of reconstruction and development. However, in Singapore, Kong (2007b) argues that the geography discipline's shape and trajectory is more fully shaped by the international as well as the national context, with global networks and flows of both teaching and research being shaped by conditions elsewhere in the world, particularly the Anglophone world, given that English is the working language in Singapore. (For other examples of geography in other contexts see the special issue of Journal of Geography in Higher Education, 2007, volume 31, 1).

International students should therefore be seen not as passive recipients of a rarefied ' $U K$ ' geographical knowledge, but as agents of the flows of geographical knowledge within the global discipline, from and to the specific places that the students are coming from. This agency is historically shaped, so that the ways in which these places have been differently tied into geopolitical relationships with Britain will influence the manner in which each individual student is inserted into HE in Britain. Nevertheless, it is not historically determined: there are great differences in the construction and development of geography in different places and international students embody these differences but also shape and offer scope for building some shared agendas.

However, these linkages are not lost but are drawn upon in constituting the category international students. And there are different ways in which the linkages are both drawn upon, but also disavowed, in order to create UK education as desirable. For example, one important tool in the arsenal of connections on which to draw in international students is language. For example, organisations such as the British Council (itself a successful postcolonial institution) have utilised the postcolonial power of English in trying to sell UK postgraduate degree. 'You'll gain recognised and respected qualifications', 'It's fantastic value'. 'You can improve your English' 
(http://www.educationuk.org/pls/hot_bc/page_pls_user_article? $\mathrm{x}=516513202912 \& \mathrm{y}=0$ \&a $=0$ \&d $=1143$, accessed July 2007) draw on the discourse of the universality of English language ${ }^{\text {xii }}$ (see Kachru, 1995 and Wa Thiong'o, 1981) and the value of the UK as the home of that language.

However, while the UK can claim to be the centre of English language, it is the wider purchase of the UK and its language that allows the British Council to talk about the universal value of an English education, which is 'respected and valued all over the world' and will 'give you an edge over the competition'. But colonialism has also multiplied the sites where such transferable knowledge may be acquired. Thus, Waters (2006) shows how international education allows middle class people from Hong Kong to accumulate a valuable form of cultural capital through a Western university degree and to use this to reproduce and even enhance their social class positionings back home in Hong Kong ${ }^{\text {xiii }}$. These findings are also echoed by Koehne's (2006) work with international students. In an interview with a male Malaysian Indian $\mathrm{PhD}$ student studying in Australia, Koehne's $(2006,244)$ found that an Australian education provides the very thing that the UK can claim to provide - social mobility through language:

'...I think we have to agree that, especially in the urban areas the English language has a tremendous influence....there are a lot of the thought patterns, the way you see the world, a lot of it is influenced by English.... f felt that the English way of immense benefit, because, look at the kind of information you are going to get using another other language, and the access to knowledge through the English language is tremendous, right, so it is a gateway to knowledge, and in my country at least right now if you have a good proficiency level, if you are competent, lots of opportunities, so I see it as social mobility as well'.

Australia has also strengthened its position relative to the UK in recruiting international students both through its physical proximity to the big south and south east Asian markets but also by 
embedding its relationships with students by offering half the migration points needed to settle in Australia to those who obtain a postgraduate qualification there.

Another long-lost colony - the US - also has had an even greater drawing power for international students, because of the numerous grants it offers international students. A recent report by Asthana (2007) thus suggests that Britain's reputation as a world leading destination for international students could thus be under threat, as 30 percent of international students do not think the education they receive is worth the money. Thus the UK share in the international student market has fallen from 16 percent in 1998 to 11 percent in 2004, with Chinese students in particular going to the US instead, owing to greater numbers of scholarships. Asthana $(2007,17)$ quotes a Kenyan female student who came to the UK to study:

'People are asking whether it is worth the risk, effort and hassle. In the past, if you had the chance to study in the UK you grabbed it with both hands, but not any more. Increasingly students are looking elsewhere.'

We give these examples not to argue for the weakening of colonial ties but instead to exemplify the multiplication of imperial sites in and through colonialism. White settler colonies, populated by considerable numbers of white English migrants, in particular (but not only) become alternative centres from which the hegemony of English can be enacted. But colonialism has also spawned other centres with African students (from countries who were part of the old British Empire) moving to India to study and so on. This multi-sitedness is itself a colonial heritage, although the UK claims and markets itself as the centre and originator of this legacy.

However, for fee paying students UK education is still, on the whole, cheaper than paying for private USHE, so for many self-funded students UKHE is a cheap option, not a privileged 
option. Similarly, while the British Council may be seen as one arm of British academic imperialism which precisely locates itself in myriad countries in order to, among other things, recruit students, other countries are not far behind. The USA, for example, has far more educational franchises in the Third World than the UK. So colonial legacies are being rewritten and the authority of British HE must be understood alongside other factors shaping international student mobility. Changes are also occurring in some of the sending countries. For example, since 1995 Malaysia has seen a rapid growth in private HE system including foreign branch campuses, local private universities and recent upgrading of private collages to degree-granting university colleges. Care must therefore be taken to recognise, but not to over determine British colonialism in explanations of the patterns of international student recruitment.

Besides, although the authority of colonialism and postcolonialism is continuously drawn upon in order to recruit students, it is precisely through the erasure of their presence that this authority is garnered. For example, geographers from around the world have come to the UK, completed their PhDs, contributed their ideas in conversations, their labour through experiments and their finances through fees, which have helped shape what British geography is today. Many have stayed too, to contest the here/there binary. Other international students have helped influence the way British geography is taught, what is written about and helped shape academic research agendas, over time. In doing so, they have brought values, ideas, theories and languages from many specific places, which intertwine with those here, to thoroughly muddy the waters of a supposedly 'pure' British intellectual geographic tradition. But, forgetting these contributions has become central to defining and marketing British $\mathrm{HE}$. 
So too has there been erasure of the agency of international students in shaping their experiences, the pedagogies and even marketing policies of HE. For example, as a female Ugandan student commented on her experience of not being able to find space to contribute to a class discussion in an Australian university:

'There was no respect to wait for somebody to speak....and I think the best way to deal with this is also to push up myself.....and then when I shared it with my other international students, they said they also experience the same thing.....so we said what can we do now? So we said we should push it. Because I saw that everyone was frustrated so we said it takes time, don't loose your confidence, go and push.' (Koehne, 2006, 253)

A further example, given by a female student at Massey University New Zealand, stated that:

'I think female postgraduate ...students who come out here are very strong characters. I think that they are very bright women. I think that they have fought their way to get here. I think they fit in extremely well...they're very special people, otherwise they wouldn't be here.'

(Scheyvens, 2005, 321)

These statements suggest the struggle that lies behind having a voice and claiming agency as an international student, especially for women. The dialogues that necessarily underpin such recognition seem to be even harder in the British context with its own particular history of race, gender and, even more importantly, class exclusions. Thus, recent research suggests that international students believe that universities in Australia (and south Africa, the US and Netherlands) are better than British ones at 'integrating' international students, developing employment links and building friendships links and relationships with their 'home' colleagues (Hodges, 2007). As one second year male student from Hong Kong who was reading biology at a London university noted (quoted in Hodges, 2007, 7):

'Normally, during practicals, students of the same racial group sit together: the British sit with the British and the Indians sit with the Indians...I think that British students and lecturers should be encouraged to talk to international students. 
Sometimes British tutors talk more to British students and ignore international students.... But forcing integration is difficult. Ultimately, it is the cultural barrier that makes students not talk to one another. Sometimes I find it hard to understand a British joke. I just don't find it funny. So, I think we should encourage mixing but we shouldn't hope for too much.'

As Newman (2007b) reports UK students demonstrate 'passive xenophobia' towards international students, some students indicating that they were reluctant to include international students in group work as it might compromise the collective mark through lack of language ability or of English pedagogy. Marking the category 'international students' as the group that 'lets the side down' highlights the common misrecognition that the UK, as the home of English, is also the place where the best English language tuition is available and to all. It is precisely through the erasure of the historical presence of English teaching around the world, its particular strength in the colonies, and the importance of class divisions in defining who and how pedagogic language is known, that such a sense of superiority is sustained.

Some UK students did report that they had benefited from the presence of international students and appreciated 'different perspectives', but in this case '...there was a sense in which many of the students wanted to establish some form of personal credentials around internationalism and exoticism, potentially linked to the burgeoning backpacking culture' (Peacock and Harrison, 2007, quoted in Newman, 2007b). Significant issues therefore remain in 'othering' international students as the 'problem group' (needing to integrate more, needing to improve language skills) and HE being heralded as the solution (by offering language services, or improved induction). Thus Wright $(1997,107)$ argues: 'Experiences of racism, culture-shock, poverty, inappropriate provision, etc., have as much to do with British society as they do with individual overseas students....improving the experiences of overseas students is not just about a new policy-and- 
resources initiative imposed from the top, but requires real and sustained dialogue between all groups in the HE sector, as well as a recognition of the active steps overseas students have always taken to help themselves.'

Thus, it is clear that international students, through their knowledge and economic resources, have 'made' (and continues to make) both British HE, and British society more generally, what it is today. As Dominic Scott, chief executive of the UK Council for International Student Affairs, said:

'It is refreshing to be reminded that international students are in fact strategically important to the UK. Their value is not just about income or internationalisation. As one commentator put it, they are not just an exotic luxury, they are 'the element that enables the whole enterprise to survive'.'(Quoted in Tysome, 2007)

We would therefore argue that UK HE, with its long history of international student attendance, is one, but only one, location of the continuous presence of the colonial and post-colonial subject 'within'. Rather, it has spawned other centres of education with which it is now left to compete for students. Yet both colonial legacies and postcolonial institutions are continuously being drawn upon to garner the authority and desirability of UK qualifications. Making explicit how these colonial histories and post-colonial imaginaries, as well as student agency itself, have shaped international students' presence in the UK moves us towards thinking more responsibly about international students, from an expanded framework that shows how contemporary spatialities continue to be located within imperial structures of power. What is also clear is that mutuality exists between here and there, or rather that the 'here' 'there' formulation is itself unsettled through a more detailed look at the flows and the abruptions that have shaped international students' presence in the British academy. But it is only through recognising these 
spatialities that any kind of responsibility for international students can be assumed. In fact, following Massey (2004), one would argue that this mutuality is important for evoking responsibility and for developing an engaged pedagogy. Responsibility is influenced by these ongoing formative relations of care, where we have all invested in each other. We explore these issues in more depth below.

\section{Towards responsibility and care in an engaged postcolonial pedagogy}

As Jazeel and McFarlane (forthcoming) argue: 'a broad and varied project of producing a postcolonial geography necessitates a more considered engagement with the concepts of responsibility and learning than currently exists in much of the extant literature connecting geographies of knowledge production and postcoloniality.' In this paper we have specifically taken up this challenge. However, we have located our discussion of pedagogy and responsibility, not within the context of the classroom, but within the context of wider internationalisation processes. So we have attempted to make visible the (often) silent presence of international students in HE in the UK, and produced a postcolonial analysis that encourages thinking responsibly about them. This is a shared responsibility (cf Young, 2003), which is activated by the affective caring register, which aims to make visible the multiple global voices already within the British geographic academy and is moved to respond to the claims made by these voices, even, and especially, if these are related in modes different to the academics (varied) own voices. But equally this is a responsibility that brings into question the normalcy of historical and contemporary unjust geopolitical conditions which underpin academic imperialism (Ake, 1979) or indeed of how and where the national begins, given the history of internationalism of which colonialism was an important part. 
As academics in the UK HEIs, we find that international students are becoming more and more important in making up the student body. Their state-fostered importance in the current academy has meant that their presence can lead to direct material benefits to academics, as the ability to attract international students has increased the financial resources flowing into their institutions, to the country and also come to be part of the criteria for promotions in some institutions ${ }^{\text {xiv }}$. Moreover, and importantly, they have also become one part of the academic's emotional and intellectual landscape.

At the same time it is crucial to note that, in the case of UK HE, the academic institutions to which international students are now integral are increasingly embedded within (not some pristine space outside of) the global neo-liberal agenda. This agenda is acute in building upon previous repertoires of global inequality and individuals embedded within UK HEIs are actively reproducing such inequalities. Thus as Berg (2006) articulates, academics are in a paradoxical position, in which they often simultaneously contest and reinforce neo-liberal practices. This is so very clearly the case with respect to international students (for example, where academics who routinely lecture about the inequities of the global trade system, may at the same time be making visits to India or Nigeria to recruit international students) but these paradoxes have received little critical attention, precisely 'because such embedding, or 'roll out' neo-liberalism, has been intimately tied up with the everyday practices of academics' (Berg, 2006, 766). It really is time that these everyday practices of inequality, and the multiple paradoxical position that academic geographers play within these structures of academic imperialism, are made visible. Calls to care and to be responsible must be set within this context. 
However, all this is occurring within the context of other wider changes within the academy. As British academics feeling the pinch of a neo-liberal system, in which work burdens and escalating administration bear down on working lives, the ability to work towards an engaged pedagogy is also increasingly becoming circumscribed. Howitt $(2000,317)$ summarises a number of difficulties currently facing many geographers in Western universities: 'University teachers are under considerable pressure. Concerns about changing patterns of government funding, increased class sizes, deteriorating teaching facilities in many institutions, market intrusions into curriculum processes, industrial organisation of the labour processes of teaching, reduced academic autonomy and increased administrative demands on teachers are repeated in many Higher Education institutions' (quoted by Scheyvens, 2003, 315).

It is in this context that we want to conclude by asking what an engaged pedagogy, informed by a 'care-full' recognition of postcolonial interaction might look like. What forms, practices and discourses would be prevalent in such an engaged pedagogy? Whilst balking against a simple 'how to do it' list, we draw on the work of others to suggest that an engaged pedagogy might include some of the following features. First, a key point is that an engaged pedagogy contests the centre from which care and responsibility can be talked about and experienced. As Fisher and Tronto (1990) have outlined, practices of care may involve attentiveness (noticing students' care needs), responsibility, competence (as an academic) and responsiveness (which involves an awareness of the different positionings and vulnerabilities of the teacher and the taught). This framework helps to unsettle the binaries between taught and teacher in fundamental ways and therefore encourages introspection over the liminalities of the boundaries between teacher and 
taught, without giving up the responsibilities of either category. This necessarily also involves a reflection of the processes of subjectivation that accompany student recruitment, not only in the constitution of the category international students, but also home students (and the erasures in its constitution). It involves consideration of how the categories of teacher and student are being affirmed, but also how can they be challenged, within every moment of interaction both within and outside the classroom. It also leads to questions about the absence of rhetoric about international teachers in the constitution of debates around international students. At what point do international students who become teachers become part of the national fabric, and how are they called upon to act on behalf of a nation?

Secondly, an engaged pedagogy would necessarily involve genuine dialogue, one that must contest the hegemonic discourse of western 'best practice' and at minimum take responsibility to care and to imagine everyday academic practices from a multitude of different perspectives and centres. To do this, frameworks of understanding will have to shift to recognise that many realities and knowledges exist and are valuable. For example, Robinson (2003) suggests some steps that might be taken to recognise the many postcolonial publics that have shaped the discipline of Geography. Thus she argues for the need to acknowledge the locatedness of theories, to demarginalise development geography, to engage with regional scholarship, and to transform the conditions of production and circulation of knowledge that now lie before many scholars in other countries. The hegemony of Anglo-American geographies and the manoeuvres of the publishing industry have left great distance therefore between what is taught and who is teaching. Hence textbook authors often have no 'live' presence in the lives of many international students. Coming face-to-face with authors can be a moment of awe but it can also help students 
to recognise their own agency within the discipline. Facilitating this agency through modes of teaching, and not just content of teaching, and building up a sense of entitlements may be one part of engaged pedagogy. Similarly, Gregory (2005,186-8) suggests a range of 'counter geographies' that can work to emphasise postcolonial connection, counteracting colonial and neo-colonial distancing strategies: contextual geographies that reveal the material realities of other people's lives; contrapuntal geographies that highlight global connections and relationships; cosmopolitan geographies that emphasise commonalities; and collaborative geographies in which partnerships are formed between academics in different countries. What new forms of subject formation can be enabled through such partnerships and genuine dialogue what interpretive repertoires may be opened up which focus less on the sticky place-based identifications of a national order and instead move towards a recognition of education as a universal good that is already set within terms of mobility..

Thirdly, we would argue that this pedagogical engagement needs to manifest itself well beyond teaching practice and into everyday practices of caring and responsiveness beyond the classroom, to understand how historically produced political structures, institutional cultures and policies shape international student experiences and recruitment. An engaged pedagogy would therefore be mindful of the broader discourses, power hierarchies, and social relations that frame international students' presence in the UK. As a result it is important that the responsibility to care is not simply 'privatised' to the level of the individual academic and their classroom pedagogic strategies. Instead, it must also be seen as a broader 'social' response: political structures, institutional cultures and policies, and the people that police these, must be challenged to care, to be politicised to be responsible for the inequitable implications of their regulatory and 
marketing policies. So whilst we agree with Jazeel and McFarlane (forthcoming) that as individuals academics are responsible to students especially (but not only) in their teaching practices, we also urge that administrators, vice chancellors, marketing managers and civil servants (through government and university institutions, policies and structures) be challenged to be responsible. We would urge that all those involved in UK HEIs become familiar with, and reflect upon, the conditions of overseas recruitment and to reflect on how 'international' students are discursively framed within recruitment debates, contextualising their own role in how such students came to be here in the first place. And that self-introspection may force consideration of the costs in the forms of subjectivation that are undergone in practices of recruitment and disciplining of international students. For example, how are we being produced as academic teachers, but also what forms of power are we being subjected to?

Fourthly, an engaged pedagogy cannot be conceived a priori, as it is necessarily deeply contextual and place specific. Here we are not simply talking about institutional and national context, but the varying context, hierarchies and sometimes competition between students (who occupy varying positions in terms of class positions, material resources, funding opportunities, language abilities, familial support in Britain, opportunities to work, age based hierarchies etc) and the varying context of academics (sexuality, class, race, gender and age power hierarchies, differential insertion into institutional structures, varying non-work commitments etc). Here we are not suggesting an endless (longing) search for difference but rather an acceptance of the possibility of both commonalities and differences at all times. 
Fifthly, however, we must be mindful of the quandaries raised in an attempt to materialise an engaged pedagogy because of the complexities involved. This means that an engaged pedagogy is probably risky too (in some places and some times and for some people) because the instability of the nature of responsibility and care means that even if in constant dialogue, we might get it wrong at times too. And this process will therefore involve deep (everyday) emotional investments of joy sacrifice and commitment. Furthermore, academic ability to be responsible and to care may also be circumscribed by lives well beyond the academy: by family commitments, by financial debts, by community work- all of which may squeeze time and emotional strength and limit the ability to care. Besides, just as for students, for academics too, temporalities from the past may set the scenes of engagement with international studentsspecific personal family histories (as active colonisers, as colonisers and colonized who resisted those power relations, as the colonized population compliant with colonialism, as citizens simultaneously experiencing colonization and colonized etc) may well influence commitment to the international student agenda. All these factors suggest that sometimes taking a responsible position is actually a recognition of the limitations of one's ability to care, for example, by refusing to take (yet another) international postgraduate student in order to 'bolster' recruitment targets. In other situations, taking responsibility may involve refusing to collude with line managers, marketing committees and the like, who actively recruit students without taking the pedagogic responsibilities entailed by taking recruitment seriously. It may involve recognising and critiquing the role of UKHEIs in creating the underdevelopment of individuals and families in poorer countries who are making horrendous financial sacrifices (for generations) to enable a family member to experience a (not-so) British education. This suggests that there are always limits to care and responsibility and that these are always in negotiation, brokered by institutional 
locations, inter-personal power relations, personalised ethics. But it also suggests that there is some ability to overcome institutional framings to establish relations beyond that, to affect and destabilize specified local forces at particular points in time ${ }^{\mathrm{xv}}$.

To conclude, in this paper we have viewed engaged pedagogy from a postcolonial frame. This has involved both rethinking and unsettling the spatialities involved in international student mobility and in relocating the 'voice' through which such concerns are articulated. As such, we have firstly argued that postcolonialism demands that engaged pedagogy is viewed as (mostly) a complex form of interdependence and mutuality which challenges the idea of proximate and distant relations and questions the centre from which international students are analysed. Secondly, we have shown that the 'centre' of the British academy is not solid, but is (and has always been) unstable, fractured and contested, brimming with multitudinous claims. It is our responsibility to hear and act upon these claims and to make space for the highly differentiated forms of care and responsibility arising from the viewpoint of international students themselves. These are fundamental issues, which refute tendencies to locate postcoloniality 'elsewhere' but rather recognises the interdependence and mutuality that shapes the postcolonial present. Lines of caring and responsibility are therefore unclear and not wholly pre-decided but do have traces from the past and implications for the future. Thus the example of international students bring forth complex spatialities of responsibility which suggests that for academic geographers working in Britain, responsibility must be seen as reflexive, as one that already recognises that postcoloniality alters internationalisation in the UK HE system and changes the frame of who can make claims to being part of British geography. It is our responsibility to acknowledge that presence, to recognise the inability to make visible that presence as loss and to respond to the 
claims that arise from this presence. There are no easy answers but one thing that is clear is that postcolonial responsibility and care fold up, and reopen, space in complicated ways. 


\section{References}

Abiri, E. 2000. The Securitisation of Migration: Towards an Understanding of Migration Policy Changes in the 1990s - the Case of Sweden. Department for Peace and Development Research, Gothenburg University.

Ake, C., 1979. Social Science as Imperialism: The Theory of Political Development. Ibadan University Press, Ibadan.

Asmar, C., 2005. Internationalising students: reassessing diasporic and local student difference. Studies in Higher Education 30 (3), 291-309.

Asthana, A., 2007. Costs deter foreign students. The Observer Newspaper. $16^{\text {th }}$ September, 17.

Attwood, R., and Tahir, T., 2007. UK fails to integrate overseas students. Times Higher Educational Supplement. 5th October 2007.

Baas, M., 2006. Students of migration: Indian overseas students and the question of permanency. People and Place. 14(1), 8-23.

Barnett, C., 2005. Ways of relating: hospitality and the acknowledgement of otherness. Progress in Human Geography 29 (1), 5-21. 
Barnett, C., Robinson, J., and Rose, G. 2008. Eds. Geographies of Globalization: A Demanding World. London: Sage.

Barnett, C., and Land, C., 2007. Geographies of generosity: beyond the 'moral turn'. Geoforum 38, 1065-1075.

Berg, L., 2006. Hierarchical space: geographers and neo-liberalism. Progress in Human Geography 30(6), 747-782.

Bhabha, H., 1993. The Location of Culture. Routledge, London.

Bhardwaj, K.K., 1997. Education and technical training for Africans in India. Africa Quarterly $37(1-2), 187-206$.

Biggs, J., 2003. Teaching for Quality Learning at University. Maidenhead, Open University Press.

Bonnett, A., 2003. Geography as the world discipline: connecting popular and academic geographical imagination. Area 35, 1 55-63.

Bosco, F.J., 2007. Hungry children and networks of aid in Argentina: thinking about geographies of responsibility and care. Children's Geographies 5, 55-76. 
Bradley, G., 2000. Developing globally-competent university teachers. Innovations in Education and Training International 37 (3), 244-253.

British Council 2004. Vision 2020: Forcasting International Student Mobility - a UK Perspective.

British

Council,

UK.

Brunch, T., and Barty, A., 1998. Internationalising British higher education: students and institutions: In Scott, P. (Ed) The Globalisation of Higher Education. Society for Research into Higher Education and Open University, Buckingham, pp. 18-31.

Brock, G., 2005: Does obligation diminish with distance? Ethics, Place and Environment 8(1), 320.

Bullen, E., and Kenway, J., 2003. Real or imagined women? Staff representations of international women postgraduate students. Discourse 24 (1), 35-49.

Burbules, N., and Torres, C., Eds. 2000. Globalisation and Education: Critical Perspectives. Routledge. London.

Corbridge, S., 1993. Marxisms, modernities, and moralities: development praxis and the claims of distant strangers. Environment and Planning D: Society and Space 11, 449-472. 
Echanove, F., 2005. Globalisation and restructuring in rural Mexico: the case of fruit growers. Tijdschrift voor Economische en Sociale Geografie 96(1), 15-30.

Findlay, A.M., and Stam, A., 2006. International student migration to the UK: Training for the global economy or simply another form of global talent recruitment? Paper prepared for a meeting on 'International competition for S\&E students and workers' Institute for the Study of International Migration, Georgetown University, Washington, 30-31, March 2006

Fisher, B. and Tronto, J. 1990. Towards a feminist theory of caring. In E. Abel and M. Nelson Eds. Circles of Care. Work and Identity in Women's Lives. Albany, State University of New York Press.

Gacel-Ávila, J., 2005. The internationalisation of higher education: a paradigm for global citizenry. Journal of Studies in International Education 9(2), 121-136.

Gibson, C., 2006. Decolonizing the production of geographical knowledges? Reflections on research with indigenous musicians. Geografiska Annaler, Series B: Human Geography 88(3), 277-284.

Gilmartin, M., and Berg, L., 2007. Locating postcolonialism. Area 39(1), 120-124.

Gregory, D. 2005. Geographies, publics and politics. Progress in Human Geography 29, 165-193. 
Haggis, T., 2003. Constructing images of ourselves? A critical investigation into 'Approaches to Learning' research in higher education. British Educational Research Journal 29(1): 89-104.

Haigh, M., 2002. Internationalisation of the Curriculum: designing inclusive education for a small world. Journal of Geography in Higher Education 26(1), 49-56.

Hazen, H.D., and Alberts, H.C., 2006. Visitors or immigrants? International students in the United States. Population, Space and Place 12 (3), 201-216.

Hobson, K., 2006. Environmental responsibility and the possibilities of pragmatist-orientated research. Social \& Cultural Geography 7(2), 283-298.

Hodges, L., 2007. Overlooked and over here. The Independent. $27^{\text {th }}$ September, 6-7.

hooks, bell 1994. Teaching to Transgress: Education As the Practice of Freedom. Routledge, New York.

hooks, bell 2003. Teaching Community. A Pedagogy of Hope. Routledge, New York.

Howitt, R., 2000. Editorial: for whom do we teach? Journal of Geography in Higher Education 24(3), 317-324.

Jackson, M.G. 2003. Internationalising the university curriculum. Journal of Geography in Higher Education 27(3), 325-340. 
James, W., 1993. Migration, racism and identity formation: the Caribbean experience in Britain. In James W., and Harris, C., Eds. Inside Babylon: The Caribbean Diaspora in Britain. Verso, London, 231-287.

James, W., 1998. Holding Aloft the Banner of Ethiopia: Caribbean Radicalism in Early Twentieth-Century America. London, Verso

Jarvis, P., 2000. The changing university: meeting a need and needing to change. Higher Education Quarterly 54(1), 43-67.

Jazeel, T., and McFarlane, C., forthcoming. Responsible learning: cultures of knowledge production and the north-south divide. Antipode

Kachru, B., 1995. The alchemy of English: In Ashcroft, B., Griffiths, G., and Tiffin, H., Eds. The Postcolonial Studies Reader. Routledge, London, 291-295.

King, R., and Ruiz-Gelices, E., 2003. International student migration and the European "Year Abroad": effects on European identity and subsequent migration behaviour. International Journal of Population Geography 9(3), 229-252.

Kincaid, J., 1996. The Autobiography of my Mother. Vintage, London. 
Khadria, B., 2007. Adversary Analysis and Optimizing the Macro-economic Stakes of Transnational Divide in Migration for Development. Paper presented at the conference on 'Transnationalisation and Development(s): Towards a North-South Perspective', Center for Interdisciplinary Research, Bielefeld, Germany, May 31 - June 01, 2007.

Khadria, B., 2001. Shifting paradigms of globalization: The twenty-first century transition towards generics in skilled migration from India. International Migration 39 (5), 45-71.

Koehne, N., 2006. (Be)coming, (Be)Longing: ways in which international students talk about themselves. Discourse: studies in cultural politics of education 27 (2), 241-257.

Kong, L., 2007a. The promises and prospects of geography in higher education. Journal of Geography in Higher Education 31 (1), 13 - 17.

Kong, L., 2007b. Geography's place in Higher Education in Singapore. Journal of Geography in Higher Education 31 (1), 39 - 56.

Kuptsch, C., 2005. Globalization and higher education: the migration of students from developing countries to Western Europe. Journal of Comparative Labour Relations 55, 149-156. 
Lahiri, S., 2000. Indians in Britain: Anglo-Indian Encounters, Race and Identity, 1880-1930. Frank Cass, London.

Lavia, J., 2007. Repositioning pedagogies and postcolonialism: theories, contradictions and possibilities. International Journal of Inclusive Education 1(3), 283 - 300.

Leonard, D., Pelletier, C., and Morley, L. 2003. The Experiences of International Students in UK Higher Education: a review of unpublished research. Available at http://www.ukcosa.org.uk/about/pubs_research.php (Accessed October, 2007).

Li, M., and Bray, M., 2007. Cross-border flows of students for higher education: push-pull factors and motivations for Mainland Chinese students in Hong Kong and Macau, Higher Education. 53 (6), 791-818.

Luke, C., 2005. Capital and knowledge flows: global higher education markets. Asia Pacific Journal of Education 25 (2), 159-174.

Mani, B., 2003. Undressing the Diaspora. In: Puwar, N. and Raghuram, P. (Eds) South Asian Women in the Diaspora. New York: Berg Press, 117-136.

Mashinini A., and Mashinini V., 2003. The changing pattern of student flows between Lesotho and South Africa: some policy implications. Africa Quarterly 33(4), 20-25.

Massey, D., 2004. Geographies of responsibility. Geografiska Annaler B 86, 5-18. 
Mather, C., 2007. Between the 'Local' and the 'Global': South African Geography after Apartheid. Journal of Geography in Higher Education 31 (1), 143 - 159.

Mbembe, A., 2001. On the Postcolony. California, University of California Press.

Mills, D., 2006. Life on the hill: students and the social history of Makerere. Africa: The Journal of the International African Institute 76(2), 249-266.

Mufti, A., 2005. Global Comparativism. Critical Inquiry 31, 472-489.

Ndoleriire, O., 2003. Education in India: opportunities for African students. Africa Quarterly 43(1), 103-110.

Newman, M., 2007a. Subsidise foreign students to keep them coming, Hepi says. Times Higher Education Supplement. 13 ${ }^{\text {th }}$ July 2007.

Newman, M., 2007b. Students shun foreign peers. Times Higher Education Supplement. 5th October 2007.

Noxolo, P., Raghuram, P., and Madge, C., 2008. Geography is pregnant and geography's milk is flowing: metaphors for a postcolonial discipline. Society and Space D. 
Ock Park, S., 2004. The Influence of American geography on Korean geography. GeoJournal 59 (1), 69-72.

Popke, J., 2006. Geography and ethics: everyday mediations through care and consumption. Progress in Human Geography 30, 504-512.

Puwar, N., and Sharma, S. 2007. Short-circuiting knowledge production. Darkmatter: postcolonial futures available at: http://www.darkmatter101.org/site/2007/05/13/short-circuitingknowledge-production/ (Accessed May 2007)

Ramsden, B., 2001. Patterns of Higher Education Institutions in the United Kingdom: a draft report for the longer term strategy group of Universities UK. London, Universities UK.

Rizvi, F., 2005. Postcolonial perspectives on globalisation and education. AERA 2005 SIG, ACM invited talk. Available online at: http://www.aera.net/uploadedFiles/SIGs/Postcolonial_Studies_and_Education_(153)/Working\% 20papers(5).pdf (accessed July 2007).

Rizvi, F., Lingard, B. and Lavia, J. 2006. Postcolonialism and education: an introduction to a contested terrain. Pedagogy, Culture and Society, 14(3), 249-262.

Robinson, J., 2003. Postcolonialising Geography: tactics and pitfalls. Singapore Journal of Tropical Geography 24(3), 273-289. 
Sander-Staudt, M., 2006. The unhappy marriage of care ethics and virtue ethics. Hypatia 16(4), 21-39.

Scheyvens, T., Wild, K., and Overton, J., 2003. International students pursuing postgraduate study in geography: impediments to their learning experience. Journal of Geography in Higher Education 27(3), 309-323.

Schoorinan, D., 1999. The pedagogical implications of diverse conceptualizations of internationalization: A U.S. based case study. Journal of Studies in International Education 3 (2), 19-46.

Schuherholz-Lehr, S., 2007. Teaching for global literacy in higher education: how prepared are the educators? Journal of Studies in International Education 11, 180-204.

Scott, D., 2002. The Sovereignty of the Imagination: An Interview with George Lamming. Small Axe 12(2), 72-200.

Sen, S., 2003. The politics of deracination: empire, education and elite children in colonial India. Studies in History 19, 19-39.

Singh, P. and Doherty, C. 2004. Global cultural flows and pedagogic dilemmas: teaching in the global university contact zone. TESOL Quarterly 38 (1), 9-42. 
Teichler, U., 2004. The changing debate on the internationalisation of higher education. Higher Education 48(1), 5-26.

Tremblay, K., 2005 Academic mobility and immigration. Journal of Studies in International Education 9 (3), 196-228.

Tronto, J.C., 1993. Moral Boundaries: A Political Argument for an Ethic of Care. Routledge, New York.

Tucker, A., 1995. Decoding ESL: International Students in the American College Classroom. NH, Boynton/Cook.

Tuhiwai-Smith, L., 2003. Decolonizing Methodologies: Research and Indigenous Peoples. Zed, London.

Tysome, T., 2007. Overseas students aid 'renewal' Times Higher Education Supplement. 14 September 2007.

UKCOSA 2004. Broadening Our Horizons: International Students in UK Universities and Colleges. UKCOSA, UK. (available at http://www.ukcosa.org.uk/survey/index.htm)

Walker, P., 1999. Market research: a poor substitute for a scholarly investigation into international education issues in Britain. Journal of International Education 10, 1, 6-13. 
Wa Thiong'o, N., 1981. Decolonising the Mind: The Politics of Language in African Literature. James Currey, London.

Waters, J., 2006. Geographies of cultural capital: education, international migration and family strategies between Hong Kong and Canada. Transactions of the Institute of British Geographers $31(2), 179-192$.

Wright, C., 1997. Gender matters: access, welfare, teaching and learning. In McNamara, D. and Harris, D. (eds) Overseas students in higher education: issues in teaching and learning. London:, Routledge. pp. 91-107.

Xiaojian, L. Yunfeng, K. and Baoyu, P. 2007. Development of geography in higher education in China since 1980. Journal of Geography in Higher Education 31 (1), 19 - 37.

Young, I.M., 2003. From guilt to solidarity: sweatshops and political responsibility, Dissent, Spring, 39-44.

Ziguras, C., and Law, S., 2006. Recruiting international students as skilled migrants: the global 'skills race' as viewed from Australia and Malaysia. Globalisation, Societies and Education 4 (1), $59-76$. 


\section{Notes}

${ }^{i}$ We use the term international student, as it is well-know point of reference. However, we are equally clear that it is a problematic term, for it signals an 'othering', for what may be seen to be international from a British perspective may not be viewed as such from a different geopolitical centre. Moreover, in many situations there is no clear distinction between 'international' and 'local' students. At other times, this distinction becomes much clearer as the duration of movement and the shifting nature of the space of circulation (as both free movement within the European Union and increasing differentiation between different nations within the United Kingdom), alter who is international, and when. More work is needed as to what forms this internationalisation takes in different spaces and places for different students.

ii This mobility of international students is multi-sited. Some students travel along established colonial routes in postcolonial contexts, as for example from Cape Verde to Portugal or India to the UK (Khadria, 2001). Others move to geographically proximate locations, such as students in Lesotho moving to South Africa (Mashinini and Mashinini, 2003) and from mainland China to Hong Kong and Macau ( $\mathrm{Li}$ and Bray, 2007), or to locations that have become lodestars for generalised student mobility (such as the US). More complex south-south student migration can also be seen, such as that of African students to India (Bhardwaj, 1997; Ndoleriire, 2003).

iii Based on the most recent UK HESA statistics available.

${ }^{\text {iv }}$ It is assumed that the main audience of this paper is academic geographers. However, they are clearly not a homogenous group, with a myriad of positions with respect to internationals students. In fact, the boundary between academic and international student is itself labile, as this paper argues.

${ }^{v}$ We refer to the UK Higher Education system in this paper. We recognise that there are many limitations with this scale of analysis (see below) but this is the only scale for which data are available, thus 'forcing' this particular scalar approach. It would, for example, probably be more accurate to refer to the English Higher Education system, as the historical relations shaping student mobility to Wales, Scotland and Northern Ireland and other parts of the world, are very different to those of England. Moreover, the Higher Educations systems in these nations are also different and will produce different relationships with international students. For example, the UKCOSA (2004) survey on International Students in UK Universities and Colleges specifically highlighted variations in the data for Scotland, Wales and England in demographics, overall satisfaction levels, finances, accommodation, social integration and employment. It is therefore a short-coming to conflate England with Britain or the UK (see http://www.ukcosa.org.uk/survey/UKregions.doc). Also, immigration regimes vary in these different nations, with Scotland, for example, offering a different set of immigration regulations for those completing degrees from their universities, making Scotland more attractive to some international students (see 'Fresh Talent: Working in Scotland Scheme' http://www.ukcosa.org.uk/images/workafter.pdf, accessed July 2007). Similarly, we talk about British Geography as this is specific from, for example, Irish Geography. 
${ }^{\mathrm{vi}}$ However, it is important to state here that these data are based upon one particular category of international students, i.e. those who come to the UK and have not been eligible for homestudent fees. This is a diverse body which includes the children of migrants who have been here for up to five years but who have no settled status and are therefore not eligible for home student fees. It also includes those who came to the UK for schooling and continued into Higher Education but are not eligible for home-student fees because they have not lived in the country for purposes other than education for three years. Finally, it also includes UK citizens who have been outside the EEA for the past three years and are primarily in education. On the other hand, migrants who have been in the UK for three years for purposes other than education may classify for fee purposes as home students, as do EEA students. So the category of international students includes a range of different students with different immigration statuses. And this means that they have different rights of further stay, of employment and rights to housing during the 'writing up period' of a research postgraduate course etc. It also suggests that the boundaries of the category international are porous, change with time and extend far beyond any simple racial or national boundary.

vii Within geography, the situation is as follows. In 2005/6, the number of EU students as a proportion of the total HE international students in Social and Human Geography was 3 percent, compared to 5 percent for non-EU students. For Geography and Environmental Science, the contribution of EU students was 7 percent compared to 16 percent non-EU (adapted from http://www.hesa.ac.uk/holisdocs/pubinfo/student/subject0506.xls).

viii For example, a recent report by the British Council (in association with Universities UK and IDP Education Australia) entitled 'Vision 2020: Forecasting international student mobility - a UK perspective' presented a forecast concerning the demand for Higher Education places throughout the world by international students. The findings were based on detailed analysis of demand for places in the English speaking destination countries from 144 countries. Some key forecasts included: global demand for international student places in English speaking destination countries was likely to increase from the current 1 million to 2.6 million by 2020; East and South Asia would account for the majority of the new demand, with China and India being the largest prospective markets; demand from the EU Accession States is likely to treble by 2010 . By 2010 it was therefore suggested that there could be more international postgraduate than undergraduate students in the UK (British Council, 2004). According to Leonard et al (2003), this expansion is likely to spawn a new range of new sites and modes of learning (a plethora of off-shore, on-line, franchised courses from public and private sector providers), new modes of partnership between universities, and potentially new modes of knowledge production (involving more interactive, user-oriented processes in groups outside or in collaboration with universities) (see also Jarvis, 2000). Associated with these recruitment drives there have been more sophisticated marketing, publicity and new contractual agreements, and attempts to harmonise qualifications across national boundaries, such as the Bologna declaration which has focused on qualifications frameworks, credit transfer and ratings across Europe (Leonard et al, 2003).

ix The large literature in this field means that this review cannot be comprehensive or complete. However it highlights some of the key issues pertaining to international students within the 
context of education. There is also a large literature which uses international students as a cohort to explore themes such as social and cultural change but we are not reviewing this here (see for instance, Mani, 2003).

${ }^{x}$ Khadria (2001) also assigns some of the blame for this backflow from the Global South to the North to the lack of effective policies in the former countries. Thus India has increased the permissible ceiling of what people can remit out of the country from 25,000 to 50,000 USD.

xi According to UKCOSA (2004), international student experiences of UK Higher Education Institutions were, on the whole, positive. Key findings indicated that $91 \%$ of undergraduates and $85 \%$ of postgraduates were satisfied or very satisfied with their course of study; $70 \%$ of respondents had used their college or university's advice service; nearly $80 \%$ of students attended an induction or orientation session; three quarters of students were offered institution-managed housing at the start of their stay and $89 \%$ of respondents were satisfied or very satisfied with their stay in the UK. The most commonly listed benefits included their academic experience, improving their English, becoming more independent and meeting people from all over the world. The report also recognised that there is scope for the UK to improve its welcome to international students. In particular, improving access to banking facilities for international students, removing barriers to employment for international students and ensuring immigration services for international students are fair, transparent and efficient. The report also advised institutions of the need to improve aspects of the information they provide to students before they arrive in the UK.

xii Also what counts as disciplinary/academic knowledge has itself been shaped through colonial encounters (see Tuhiwai-Smith, 2003), so not only is how UK Higher Education marketed important, but also what is marketed).

xiii Sen (2003) similarly gives an account of the relationship between empire, education and the 'production' of elite children in colonial India.

xiv The response of geography academics towards the recruitment of international students is as complex and multifaceted as are our relationships with them. Some of us refuse to take international students on, others blithely accept these students, even when they can not adequate supervise or teach them, whilst others actively recruit international students to either specifically bolster the university regime or to specifically challenge the hegemony of Anglo-American geography. So there is not one singular simple response to our international students: contestation, collusion and collaboration are all involved in our relationships with them, often simultaneously.

${ }^{\mathrm{xv}}$ For example, Linda Tuhiwai Smith (1999) usefully works through this recognition of both the potential and limits of academics in relation to others, in the context of non-indigenous researchers' responsibilities towards Maori researchers. 